\title{
COMPARISON OF METHODOLOGICAL APPROACHES FOR THE EVALUATION OF ECOSYSTEM SERVICES FOR OPTIONS TO DEVELOP SUSTAINABLE TOURISM FORMS (ECOTOURISM) (EXAMPLE: BRATISLAVA IV)
}

\author{
ZDENA KRNÁČOVÁ ${ }^{1}$, PETER BARANČOK ${ }^{1}$, KATARÍNA PAVLIČKOVÁ², ALEXANDRA PLATKOVÁ-DEMČÁKOVÁ ${ }^{2}$ \\ ${ }^{1}$ Institute of Landscape Ecology, Slovak Academy of Sciences, Stefanikova 3, P.O. Box 254, 81499 Bratislava, Slovak Republic; e-mail: zdena.krnacova@savba.sk \\ ${ }^{2}$ Department of Environmental Ecology and Landscape Management, Faculty of Natural Sciences, Comenius University in Bratislava, Ilkovičova 6, Mlynska \\ dolina, 84215 Bratislava, Slovak Republic
}

Corresponding author

Received: 27 November 2020 / Accepted: 26 March 2021

\begin{abstract}
Krnáčová Z., Barančok P., Pavličková K., Platková-Demčáková A.: Comparison of methodological approaches for the evaluation of ecosystem services for options to develop sustainable tourism forms (ecotourism) (Example: Bratislava IV). Ekológia (Bratislava), Vol. 40, No. 2, p. 189-200, 2021.

Ecosystem services are the benefits provided to human society by natural ecosystems, which are generally understood as the ecosystem processes that sustain human life. In particular, an ecosystem's cultural services include intangible benefits derived from aesthetic and other experiences, recreation, cognition and spiritual enrichment, and the ability to discern values. The study focuses on the comparison of two methodological approaches to the evaluation of landscape and the benefits of ecosystems for the development of ecological forms of tourism, using Bratislava IV as an example. The basis for database information is the processing of secondary landscape structure. The first methodological approach is based on a detailed mapping of land cover classes (Land Cover) in accordance with the legend of the Technical Guide CORINE Land Cover - supplement at the fourth and fifth levels of mapping in 2014-2018 and determining the degree of landscape-ecological significance. The second approach is based on creating a set of relevant indicators and their evaluation using the scaling and weighting method. We reached the conclusion that the first methodological approach is more suitable for smaller territories at the cadastral level, while the second is better suited for regional-level territories.
\end{abstract}

Key words: ecological forms of tourism, ecosystem benefits and services, landscape-ecological significance, landscape structure, indicators of landscape-ecological significance, suggestion for tourism development.

\section{Introduction}

Cultural ecosystem services mainly include immaterial experiences gained from aesthetic and other experiences, recreation, cognition and spiritual enrichment, and the ability to distinguish values.

There are currently three international classifications of ecosystem services: the Millennium Ecosystem Assessment (MEA), the Economics of Ecosystem and Biodiversity (TEEB), and the Common International Classification of Ecosystem Services (CICES) (Table 1). Each classification has advantages and disadvantages in relation to a particular context (Maes et al., 2013).

1. Based on TEEB, research (2010) suggests that cultural benefits and ecosystem services include the following:

2. Cultural diversity as a result of ecosystem diversity (environmental diversity, biological diversity, and landscape diversity).

3. Knowledge developed by different cultures based on the influence of ecosystems thereon.

4. Aesthetical values (perceptions of the beauty of ecosystems and components).
5. Recreation, ecotourism, and geotourism (ecosystems as places for free time, regeneration, and recuperation).

6. Cultural heritage values created by the influence of ecosystems and components.

The cultural diversity of landscape (preserving a nation's traditional tangible or intangible cultural forms that result from long-term development) significantly contributes to maintaining the Earth's wide range of living conditions and life forms.

A landscape's potential reflects its ability to offer certain opportunities and assumptions to different uses, and this with the aim of satisfying the needs of human society. From the anthropocentric perspective, there are ecosystems services which represent benefits for society and nature, i.e., water, food, forests, soil formation, purification of water and air, flood and drought protection, and crop pollination (DEFRA, 2007).

Numerous authors (such as Sláviková, 1975; Christ et al., 2003; Otahel', Poláčik, 1987; Krnáčová et al., 2005; Mariot, 1983; Krogmann, 2005, 2006; Healy, 1994) cite landscape potential. As an example, we will mention the research by Otahel' and Poláčik (1987) and McCool and Lime (2001). Their assessment is based

(c) The Author(s) 2021. This is an open access article distributed under the terms of the CC BY-NC-ND license.

https://content.sciendo.com/view/journals/eko/eko-overview.xml 
on the attractiveness of basic forms of land utilization, the decisive role in which is played by the primary, natural supply of land represented by grass cover, recreational areas, conservation areas, and forest cover. The secondary supply of land, which is created by humankind, and the criterion of material-technical facility and the attraction of cultural-historical buildings, is also taken into consideration.

Cultural ecosystem services provide services and benefits for tourism development through landscape, biological diversity, and preserved values of cultural heritage.

From this point of view, the following are attractive for tourism: undivided and extensive forests, submontane and mountain plants, wetlands, protected flowers, trees, and rare mammals and birds. Of equal importance are also the morphometric parameters of reliefs - a landscape's abiotic conditions. When considering what land can offer tourism, a significant role is played by natural conditions, preserved cultural-historical buildings, cultural establishments, and cultural/sports events. When determining the particular role played by its basic functions, it's also necessary to have comprehensive knowledge of the natural and cultural-historical environment of a recreational area. Such environment brings tourists closer to an area's history, architecture, technical sights, and culture.

This paper aims to compare two methodological approaches that allow the quantification of ecosystem services for the development of cultural activities; in particular, ecosystem services that support the development of ecological forms of tourism.

In this article, we have focused on verifying predetermined hypotheses:

- Whether selected indicators of both methods can be considered as complementary,

- Or whether the selected indicators of both methods in fact overlap and thus multiply the value of the land cover elements and thus national potential in terms of tourism demand,

- Or whether the selected indicators of these methods can be considered as separate criteria for different levels of land cover mapping and determining the potential of selected tourism types.

\section{Methods}

The basic database for both methods is current land cover - secondary landscape structure. Mapping of the status and characteristic elements of current land cover are processed on the third, fourth, and fifth levels based on the CORINE Land Cover Technical Guide - Addendum 2000 legend (Bossard et al., 2000). Land cover classes are processed in a vector format, which are created by the synthesis of the thematic and relevant layers as discussed in the fundamentals for a geographic information system (ZB GIS, 2012) and licensed updated databases of identified buildings based on the CORINE Land Cover legend derived from vector databases of orto-maps from aviation photographs (EUROSENSE, s.r.o., 2017). This information was supported by the research of habitats of European and national importance in 2014-2018. The database of land cover classes includes precious information about the character of habitats, the level of soil anthropization, socioeconomic manifestations of people in the landscape, and characteristics of the current tourist infrastructure. The updated database of land cover enables the selection of natural, seminatural, socioeconomic, and fabricated culturalhistorical resources. It also provides sufficient characterization for the assessment of cultural benefits and ecosystem services (1:5000 scale).

The evaluation of ecosystem services was assessed using two methodological approaches. The most important task in the first methodological approach is the landscape-ecological significance of land cover elements. Landscape-ecological significance (LES) represents the utility attribute of the landscape following from the interpretation of land cover classes. It is characterized by a natural attribute of ecosystems (land cover classes) to which various degrees of naturalness are attributed (indigenousness) preservation of vegetation cover, overall biodiversity, gene pool importance, species rareness, and endangerment - based on the degree of vegetation hemeroby (Smejkal, 1999).

A degree of landscape-ecological significance (LES) has been assigned to each element of secondary landscape structure, with a suitable ecological type of recreational activity suggested. The following overview includes some recreational types we have worked with.

Suggested types of recreation: 1 - recreational tourism; 2 cultural tourism aimed at cultural-historical sights; 3 - sports tourism; 4 - socially oriented tourism; 5 - cultural tourism aimed at natural attractions; 6 - relaxation-sports tourism; 7 - technical infrastructure; 8 - green infrastructure; 9 - civic amenities; 10 individual-relaxation-social; (-) - not assessed.

The most important task in the second methodological approach is the landscape-ecological importance of land cover categories, but grouped. This method is divided into three steps and based on the approach of Anděl et al. (2008) and Molitoris and Pavličková (2018).

In the first step, we set up natural potential indicators into categories, which are each divided into five parts with ascending point values from 1 to 5 (L1, W1, M1, G1, OA1, ON1 represent 1 point, etc., the highest value is 5), and the evaluation of protected areas' importance as well as cultural-historical potential reflects the number of those elements in the country:

\section{- Natural potential}

Forest areas (L): categories F1 to F5 have been calculated as a percentage measurement of forest area in the current landscape structure (CLS) to total measurement of the CLS: F1 (0-5\%), F2 (6-20\%), F3 (21-40\%), F4 (41-60\%), and F5 $(>61 \%)$.

Water areas (W): categories W1 to W5 have been calculated as a percentage measurement of water area in the CLS to total measurement of the CLS: W1 (0-2\%), W2 (3-5\%), W3 (6-7\%), W4 (6-7\%), and W5 ( $\geq 8 \%)$.

Meadows and pastures (M): categories M1 to M5 have been calculated as a percentage measurement of meadows and pastures areas in the CLS to total measurement of the CLS: M1 (0-2\%), M2 (3-5\%), M3 (6-7\%), M4 (6-7\%), and M5 $(\geq 8 \%)$.

Other greenery (G) (e.g., vineyards, hop yards, orchards, and gardens): categories G1 to G5 have been calculated as a percentage measurement of greenery areas in the CLS to total measurement of the CLS: G1 (0-2\%), G2 (3-5\%), G3 (6-7\%), G4 (6-7\%), and G5 ( $\geq 8 \%)$.

Other areas artificial (OA): categories OA1 to OA5 have been calculated as a percentage measurement of other areas in the CLS to total measurement of the CLS: OA1 (0-2\%), 
Ekológia (Bratislava) 2021: 40(2): 189-200

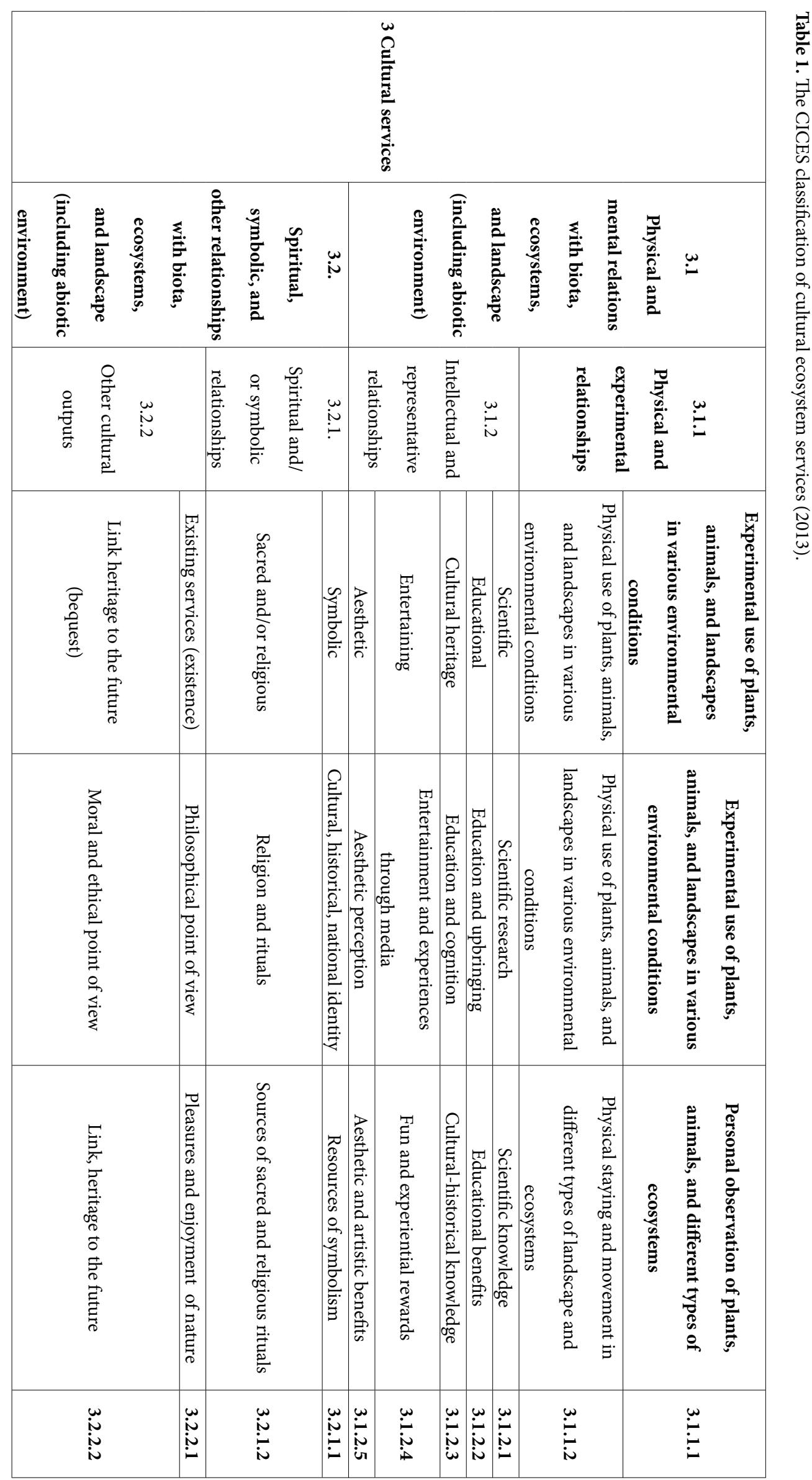


Table 2. Landscape potential for selected tourism types according to Anděl et al. (2008).

\begin{tabular}{|l|c|c|c|c|c|c|}
\hline \multirow{2}{*}{$\begin{array}{l}\text { A. Natural and cultural- } \\
\text { historical potential }\end{array}$} & Hiking & $\begin{array}{c}\text { Cycle } \\
\text { tourism }\end{array}$ & $\begin{array}{c}\text { Rural } \\
\text { tourism }\end{array}$ & $\begin{array}{c}\text { Water recreation } \\
\text { and fishing }\end{array}$ & $\begin{array}{c}\text { Cultural } \\
\text { tourism } \\
- \text { natural } \\
\text { attractions }\end{array}$ & $\begin{array}{c}\text { Cultural tourism } \\
- \text { historical } \\
\text { attractions }\end{array}$ \\
\cline { 2 - 7 } & 4 & 3 & 3 & 1 & 3 & 1 \\
\hline A1 Forest areas & 1 & 1 & 2 & 4 & 3 & 1 \\
\hline A3 Water areas & 2 & 3 & 4 & 2 & 2 & 1 \\
\hline A4 Other greenery & 2 & 2 & 3 & 2 & 1 & 2 \\
\hline A4 Other areas (artificial) & 1 & 2 & 4 & 1 & 1 & 3 \\
\hline A4 Other areas (natural) & 1 & 1 & 1 & 1 & & 2 \\
\hline B1 Protected areas & 4 & 4 & 2 & 1 & & 1 \\
\hline C1 Culture-historical sites & 3 & 4 & 2 & 1 & & 1 \\
\hline
\end{tabular}

OA2 (3-5\%), OA3 (6-7\%), OA4 (6-7\%), and OA5 ( $\geq 8 \%$ ). Other areas natural $(\mathrm{ON})$ : categories $\mathrm{ON} 1$ to $\mathrm{ON} 5$ have been calculated as a percentage measurement of other natural areas in the CLS to total measurement of the CLS: ON1 (0-2\%), ON2 (3-5\%), ON3 (6-7\%), ON4 (6-7\%), and ON5 $(\geq 8 \%)$.

\section{- $\quad$ Protected areas}

Protected areas (PA): categories $\mathrm{P} 1$ to $\mathrm{P} 5$ are specified by the number of PA units in a cadastre: PA 1 (1 protected area), PA 2 (2), PA 3 (3), PA 4 (4), and PA 5 ( $\geq 4$ ).

- Culture-historical potential Culture-historical sites $(\mathrm{CH})$ : categories $\mathrm{CH} 1$ to $\mathrm{CH} 4$ are evaluated according to urban and municipal statistics (UMS); specified by the number of culture-historical sites: $\mathrm{CH} 1$ (0-2 sites), $\mathrm{CH} 2$ (3-5), $\mathrm{CH} 3$ (6-7), $\mathrm{CH} 4$ (8-9), and CH5 $(\geq 10)$.

In the second step, we have added the weight of recreational categories according to landscape category, in the range of values from 1 to 4 (Table 2).

Those weights are put into the formula as "WI." To compare the potential with the first approach, we suggested these tourism types: hiking (similar to 3 - sports tourism), cycle tourism (3 - sports tourism), rural tourism (similar to 1 - recreational tourism and 4 - socially oriented tourism), water recreation and fishing (similar to 3 - sports tourism and 6 - relaxation-sports tourism), cultural tourism aimed at natural attractions (similar to 2 - cultural tourism aimed at cultural-historical sights), and cultural tourism aimed at natural attractions) (the same as 5). In this approach, 7 - technical infrastructure, 8 - green infrastructure, and 9 - civic amenities were not suggested.

In the third step, the resulting numerical values for the various recreational activities in each category indicator (forest areas, lakes, etc.) were put into the following formula:

$$
\mathrm{KI} \times \mathrm{VI} \text {, }
$$

where $\mathrm{KI}$ is a category indicator to the appropriate point value of $1-4$, and VI is the scale of the indicator with corresponding point value of $1-4$.

The total sum of each category indicator's point values represents the final point value of individual recreational activities.
The total sum of various recreational activities point values in all categories' indicator represents the total point value for the recreational potential of the cadastre.

The higher the point value, the greater the cadastre's potential to develop recreation.

\section{Model area}

The central area of the city part Bratislava IV's land cover is formed by extensive forest ecosystems - part of the Small Carpathians protected landscape area. The southeast includes the vast urban areas of Karlova Ves and Dúbravka cadastres. The Devínska Nová Ves cadastre includes, apart from an industrial zone, agriculturally utilized soil that is, however, gradually being developed by Bory Mall polyfunctional complexes. The cadastral area of Devín lies on the confluence of the Morava and the Danube, with key biotopes including Devínska Kobyla (national nature reserve), Devín (national nature monument), and Slovanský ostrov (protected area). Devínska Kobyla's foothills include vineyards, gardens, and scattered isolated buildings. This area can be marked as ecotone, lined with rare biotopes, that fulfils the role of a buffer zone. The cultural-historical center of the area is formed by Devín Castle (cultural monument), a Slavic fortification that documents a prehistoric settlement. From the agricultural point of view of land use utilization, vineyards and gardens are more preferred; hence, the area is less suitable for family housing (Figs 1 and 2).

In the area of interest, despite the strong anthropic pressure of Bratislava city, several types of endangered biotopes have been preserved - mainly in forest areas and Morava/Danube rivers floodplains. As such, the land surface has very high landscapeecological significance (LES).

The largest area (almost 845 ha) comprises oak-hornbeam forests in the protected landscape area of the Small Carpathians - part of the Devín Carpathians (Fig. 3). The protected area is preserved forest communities, mainly oak and oak-hornbeam forests on southern slopes with transition to xerothermic rock steppes on the northern slopes of beechwood. The willow-poplar alluvial forests along the Danube and partly along the Morava represent approximately 80 ha. Backyard gardens comprise approximately $100 \mathrm{ha}$. Watercourses, water expanses, and wetlands are 150 ha. Vineyards in this area are either abandoned or de- 


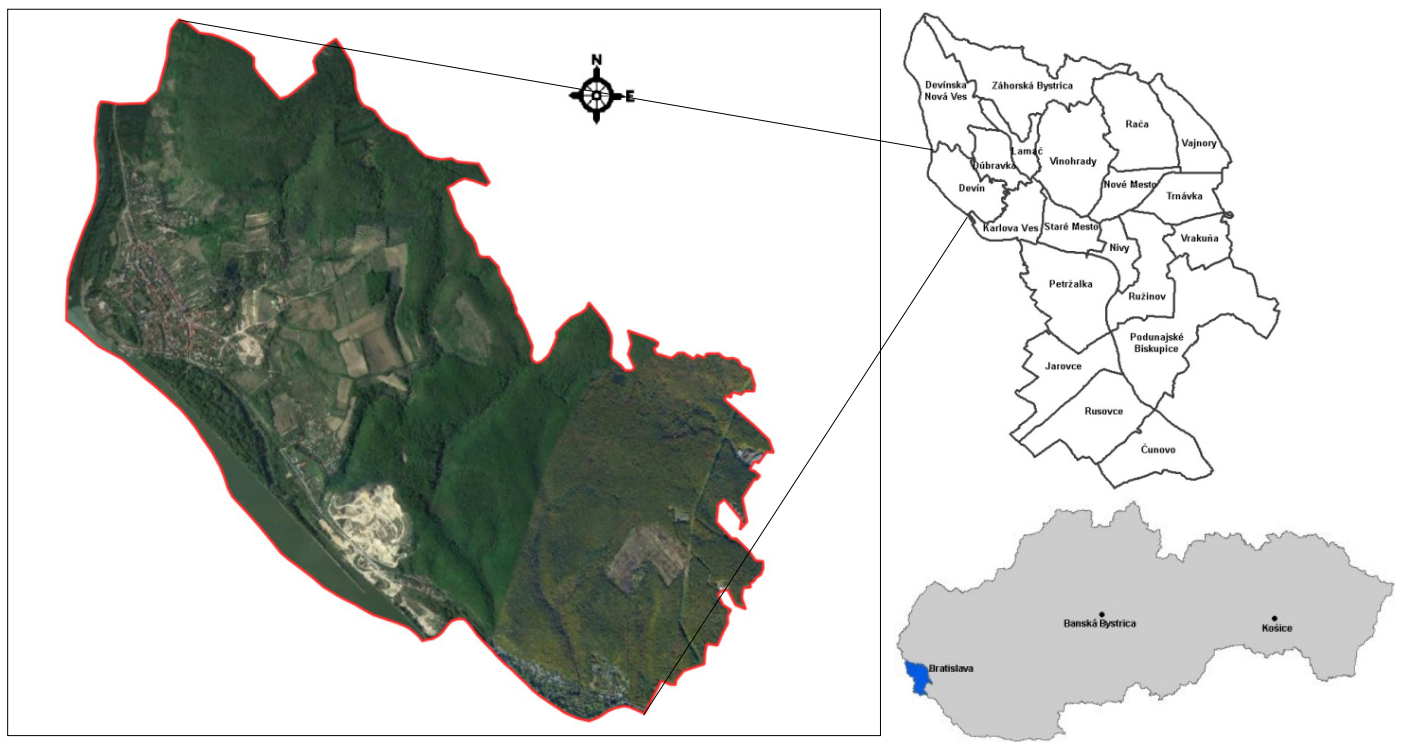

Fig. 1. Model area Devín - Bratislava IV city part.

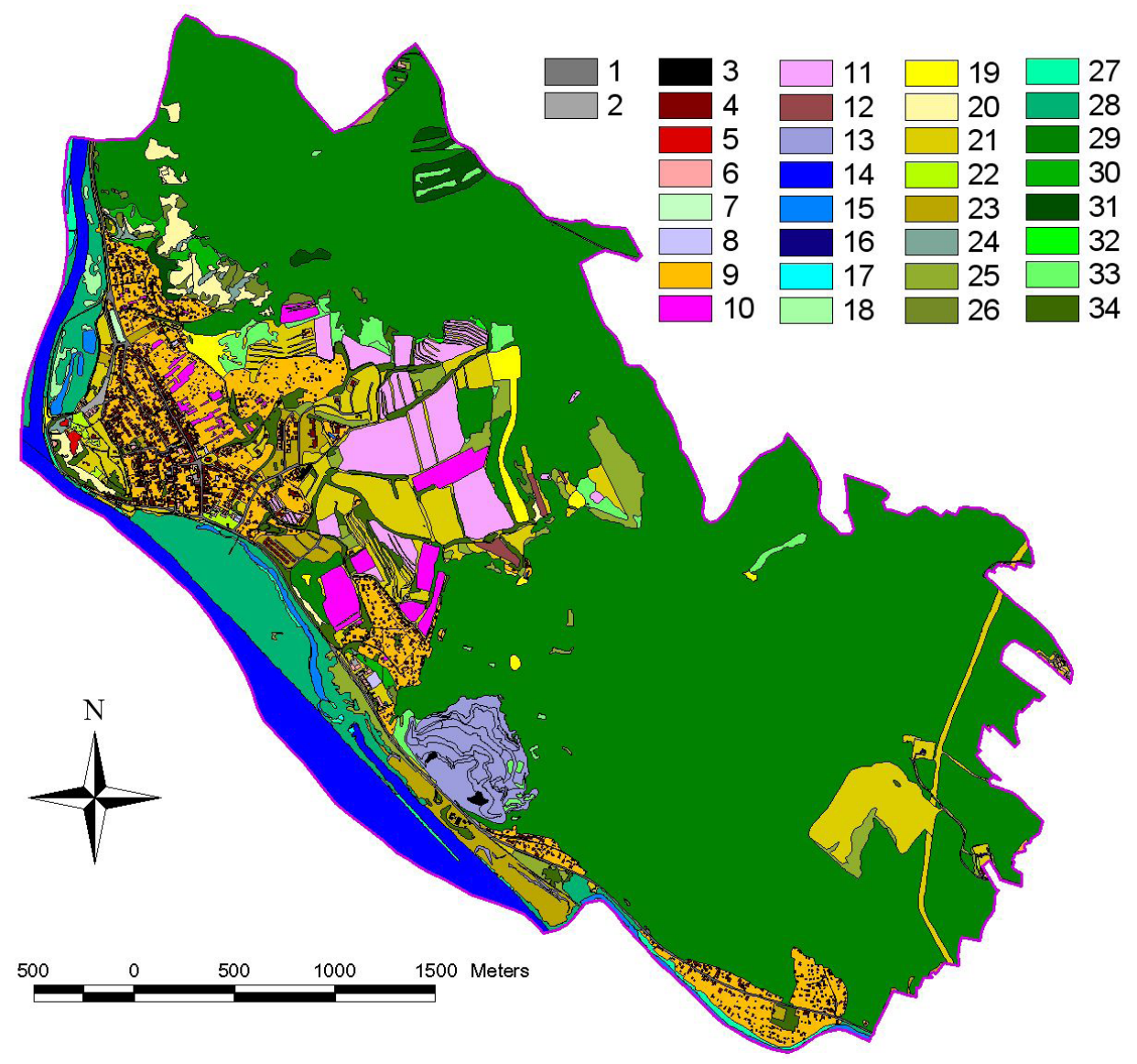

Fig. 2. Model area land cover.

Notes: 1 - roads (asphalt - roads I, II, and III local roads); 2 - paved areas (parking, loading ramps); 3 - industrial and warehouses; 4 - individual and public housing; 5 - cultural monuments; 6 - services and administration; 7 - cemetery; 8 - playgrounds; 9 - gardens; 10 - vineyards; 11 - abandoned orchards, abandoned vineyards; 12 - garden settlements; 13 - quarry; 14 - stream; 15 - water areas and dead river branch; 16 - water source; 17 - wetland; 18 - reed and flood-meadows; 19 - meadows; 20 - xero-thermophilous grassland vegetation; 21 - ruderal grasses; 22 - park grasses; 23 - abandoned areas with ruderal vegetation; 24 - rocks, rock reefs; 25 - grassy overgrown; 26 - forest-steppe vegetation; 27 - waterside - vegetation natural; 28 - soft alluvial forest; 29 - oak-hornbeam forest; 30 - xerothermic oak forest; 31 - pine forest; 32 - locust forest; 33 - young unspecified forest; 34 - nonforest vegetation surface, variety of species. 
veloped and represent approximately 30 ha. Abandoned gardens and vineyards cover 45 ha, which is just a remnant of a much wider area that was visually dominant in the buffer zone between the built-up area and forest vegetation on the Small Carpathians southern slopes. Nonforest woody vegetation is represented by various species over 70-80 ha. Ruderal grassland can be found on approximately 100 ha (Fig. 4).

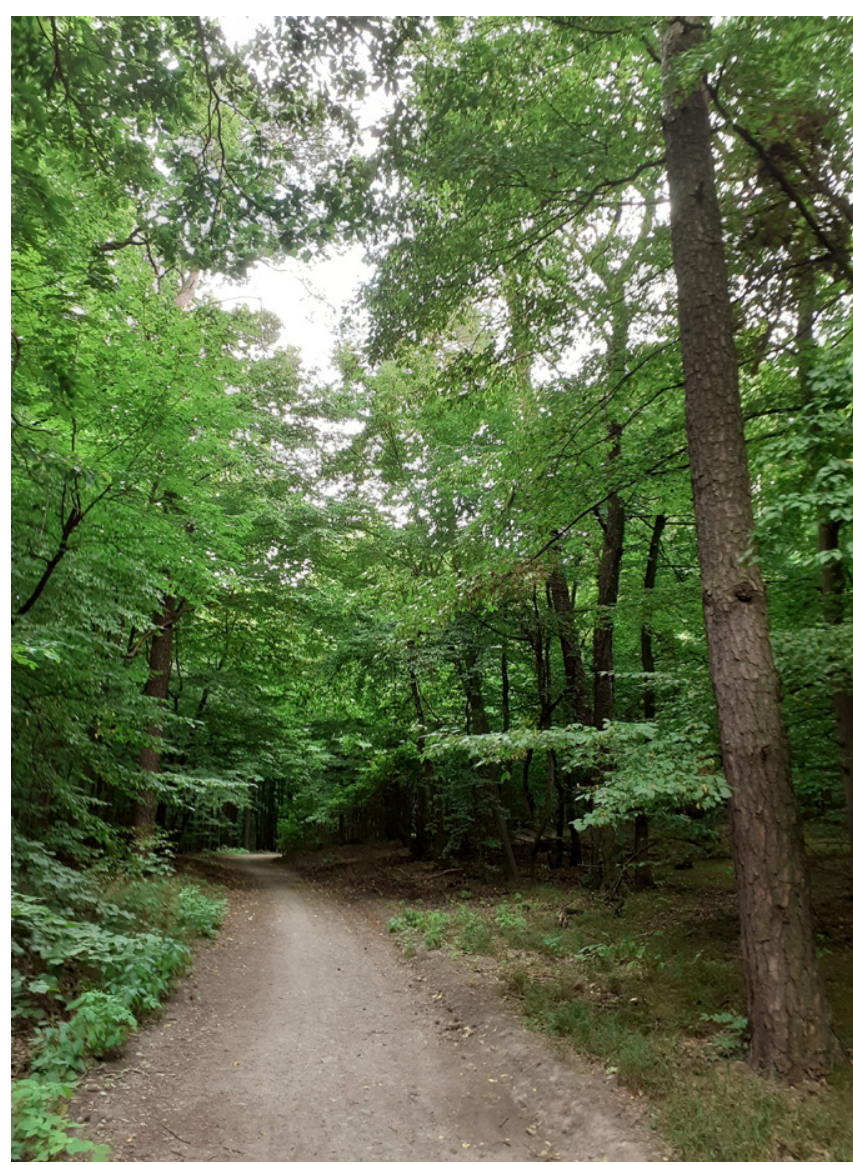

Fig. 3. Interior of Devín Carpathians (Photo: Zdena Krnáčová).

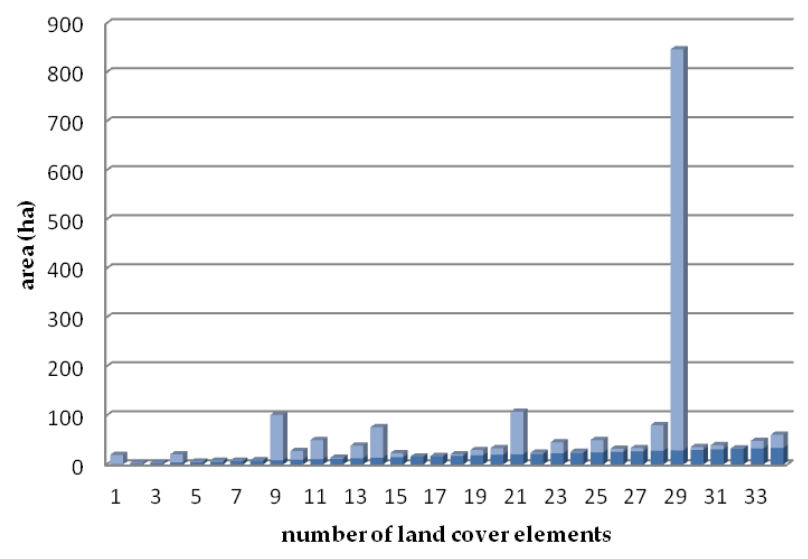

Fig. 4. Overview of landscape structure elements.

\section{Results}

In the first methodological approach, we proceed from the assessment of the hemeroby level based on Smejkal (1999), which we have adjusted based on field mapping and determining the degree of preservation, indigenousness, and originality of ecosystems. The second methodological approach proceeds from less detailed mapping, but uses a wider scale of indicators of ecological and environmental character (Krnáčová et al., 2018). The evaluation of ecosystem services was assessed by two methodological approaches.

Determining the degree of hemeroby has direct importance for the protection of nature, and also applies to the assessment of stability and resistance of communities, degree of biodiversity, etc. Such is also used to determine biological stability or when describing the various utility functions of vegetation elements in the landscape. A degree of landscape-ecological significance (LES) has been assigned to each element of secondary landscape structure, and a suitable ecological type of recreational activity has been suggested. The following overview includes some types of recreation we considered.

The landscape-ecological significance range based on the second methodological approach of the area was determined on the basis of:

- groups of land cover classes in terms of characteristic land utilization,

- $\quad$ area of groups of classes of land cover,

- elements of natural protection,

- cultural-historical monuments.

In order to compare both methodological approaches, we had to consider linking the landscape classes based on the first approach with the classes based on the second approach, while using the following links:

- Forest areas (F) - including elements of CLS 17, 25, 27-33.

- Water areas (W) - including elements of CLS 14-16.

- Meadows and pastures (M) - including elements of CLS 18 19, 20, 21.

- Other greenery $(\mathrm{G})$ - including elements of CLS 9-12, 22, 34.

- Other artificial areas (OA) - including elements of CLS 1-8, $13,23$.

- $\quad$ Other natural areas $(\mathrm{ON})$ - including elements of CLS 24 (Figs 3 and 5).

The final assessment based on the second methodological approach is shown in Table 3. Comparison of the LES assessment on the basis of both methodological approaches (Table 4, Figs 5 and 6).

As the final numerical assessment, we can write the area percentage of the individual categories of importance based on both methodological approaches (Table 5). As the second step, we compared the results of recreational types for individual CLS elements. From the results, we can state that $65-78 \%$ of the model area is of high landscape-ecological significance. To this can also be considered the selection of tourism types most nature friendly, i.e., mainly cultural tourism development aimed at nature and cultural-historical attractions. This category also includes the continuous vegetation of Devín Carpathians (protected landscape area) and Devín Castle (national cultural monument). In this area, several relaxation-sports activities were suggested, including predominantly hiking. Areas 
Table 3. The final point values of individual recreational activities (total sum - P).

\begin{tabular}{|c|c|c|c|c|c|c|}
\hline \multirow{3}{*}{$\begin{array}{l}\text { A. Natural and cultural-historical } \\
\text { potential }\end{array}$} & \multicolumn{5}{|c|}{ Types and their importance for each category } & \multirow[b]{2}{*}{$\begin{array}{c}\text { Cultural tourism - } \\
\text { historical attractions } \\
(5)\end{array}$} \\
\hline & \multirow[t]{2}{*}{ Hiking (10) } & \multirow{2}{*}{$\begin{array}{c}\text { Cycle } \\
\text { tourism (10) }\end{array}$} & \multirow{2}{*}{$\begin{array}{c}\text { Rural } \\
\text { tourism } \\
(1+4)\end{array}$} & \multicolumn{2}{|c|}{$\begin{array}{l}\text { Water recreation and fishing } \\
\qquad(3+6)\end{array}$} & \\
\hline & & & & & \multicolumn{2}{|c|}{ Cultural tourism - natural attractions (2) } \\
\hline A1 Forest areas & 4 & 3 & 3 & 1 & 3 & 1 \\
\hline A2 Water areas & 1 & 1 & 2 & 4 & 3 & 1 \\
\hline A3 Meadows and pastures & 2 & 3 & 4 & 2 & 4 & 1 \\
\hline A4 Other greenery & 2 & 2 & 3 & 2 & 2 & 2 \\
\hline A4 Other areas (artificial) & 1 & 2 & 4 & 1 & 1 & 3 \\
\hline A4 Other areas (natural) & 1 & 1 & 1 & 1 & 1 & 2 \\
\hline B1 Protected areas & 4 & 4 & 2 & 1 & 4 & 1 \\
\hline C1 Culture-historical sites & 3 & 4 & 2 & 1 & 1 & 4 \\
\hline Total & 18 & 20 & 21 & 13 & 19 & 15 \\
\hline
\end{tabular}

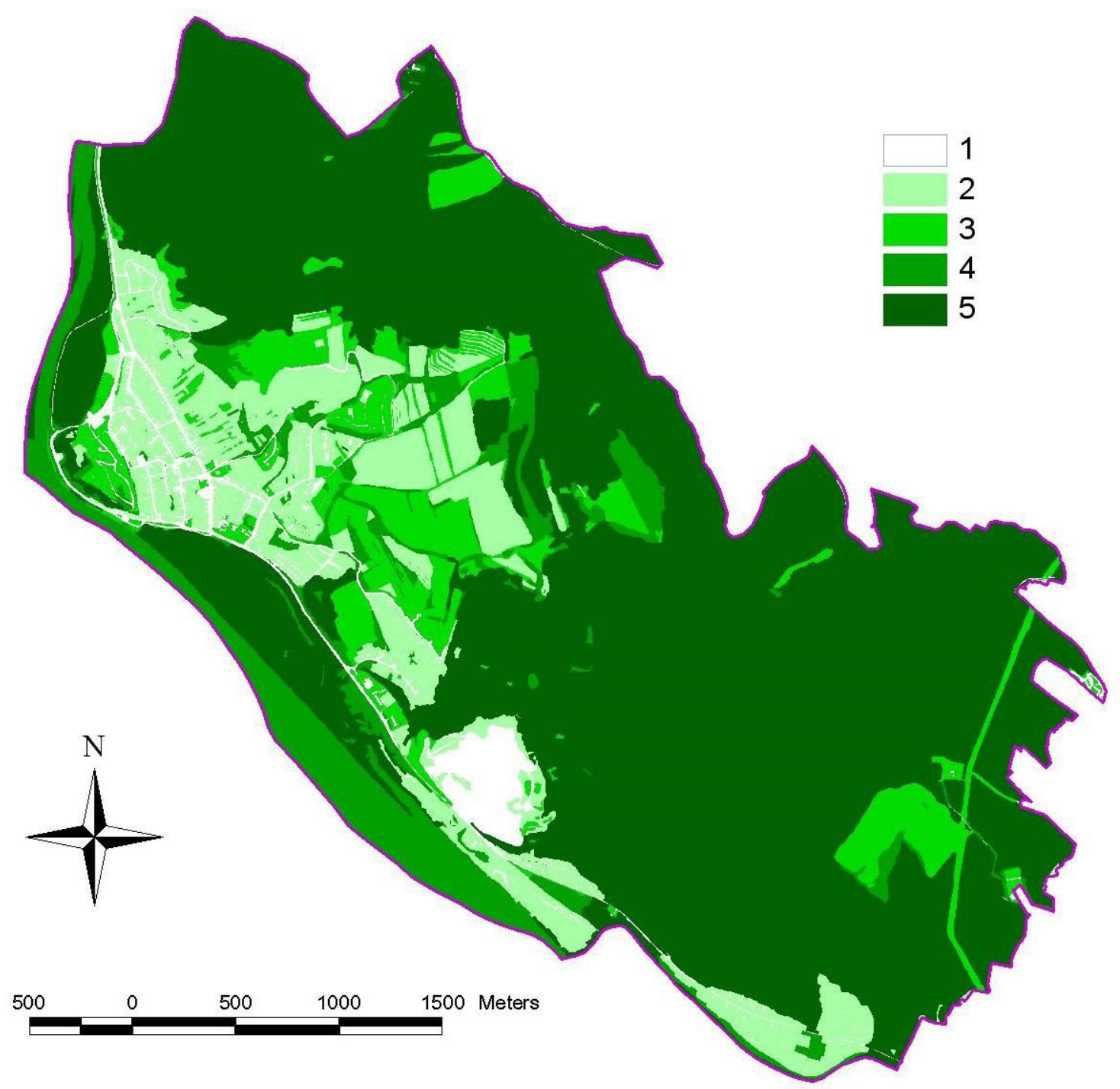

Fig. 5. Assessment of the landscape-ecological significance of land cover classes (Devín) based on the first methodological approach. Notes: V1 - very low; V2 - low; V3 - medium; V4 - high; V5 - very high. 


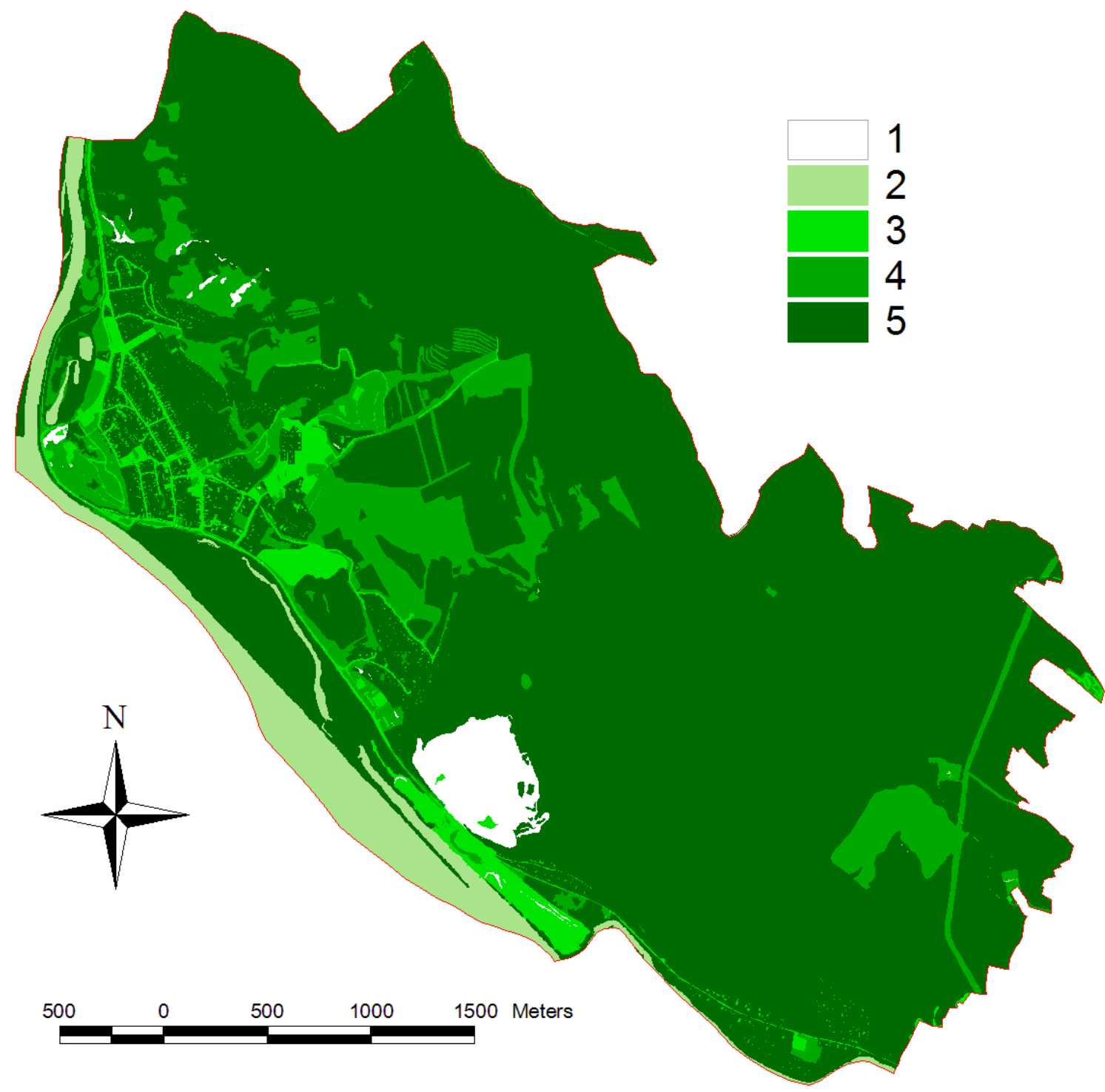

Fig. 6. Assessment of the landscape-ecological significance of land cover classes (Devín) based on the second methodological approach. Notes: 1 - very low; 2 - low; 3 - medium; 4 - high; 5 - very high.

with third and fourth degrees of LES represent less ecologically important landscape segments (16-19\%) that provide space for relaxation and sport. Both methodological approaches confirm this, with the exception that the first methodological approach offers a more detailed list of types/kinds of tourism. This is also reflected in the wider variability of tourism suggestions, and a more sensitive overall approach that considers the character of areas from their anthropogenic point of view, while the proportion of classes is based on their origin of significance as per nature preservation. Other areas are built-up. Some areas which have not been assessed are mostly productive vineyards (Table 6).

From the point of view of the landscape-ecological significance of individual types of land cover based on the first methodological approach, the most promising tourism types appear to be developing cultural tourism aimed at natural and cultural- historical attractions and relaxation-sports tourism. The former has ideal and very attractive conditions in the protected areas with continuous extensive forest areas, submontane and mountain vegetation, wetlands, forest-steppe vegetation, protected species of plants, protected woody plants, and areas of rare species of mammals and birds. For relaxation-sports activities, Devín offers spectacular natural scenery, attractive cycle paths, hiking trails, and proximity to the Small Carpathians (protected landscape area). Considered one of the most beautiful areas in Bratislava, Devín, Devín Castle and its immediate surroundings are popular for short walks. The area also has Danube riverside walks beneath castle rock and along the Morava River, and around the historical lanes of Devín (city part of Bratislava). Refreshments and restaurants are situated by the castle's car park, and the Danube riverbank welcomes numerous tourists by boat and bike. 
Table 4. Comparison of the LES assessment on the basis of both methodological approaches.

\begin{tabular}{|c|c|c|c|c|}
\hline CLS & Legend & Area (ha) & $\mathrm{V}(1)$ & V (2) \\
\hline 1 & Roads (asphalt - roads I, II, and III local roads) & 18.66 & 1 & 3 \\
\hline 2 & Paved areas (parking, loading ramps) & 1.75 & 1 & 3 \\
\hline 3 & Industrial and warehouses & 1.07 & 1 & 3 \\
\hline 4 & Individual and public housing & 16.73 & 2 & 3 \\
\hline 5 & Cultural monuments & 0.95 & 4 & 3 \\
\hline 6 & Objects of services and administration & 1.73 & 1 & 3 \\
\hline 7 & Cemetery & 0.53 & 2 & 3 \\
\hline 8 & Playgrounds & 0.6 & 2 & 3 \\
\hline 9 & Gardens & 92.11 & 2 & 5 \\
\hline 10 & Vineyards & 17.41 & 3 & 5 \\
\hline 11 & Abandoned orchards, abandoned vineyards & 38.72 & 3 & 5 \\
\hline 12 & Gardening settlements & 1.94 & 3 & 5 \\
\hline 13 & Quarry & 25.39 & 3 & 3 \\
\hline 14 & Stream & 61.98 & 4 & 2 \\
\hline 15 & Water areas and dead river branch & 8.28 & 5 & 2 \\
\hline 16 & Water source & 0.22 & 2 & 2 \\
\hline 17 & Wetland & 0.28 & 5 & 5 \\
\hline 18 & Reed and flood-meadows & 2.8 & 5 & 4 \\
\hline 19 & Meadows & 10.6 & 4 & 4 \\
\hline 20 & Xero-thermophilous grassland vegetation & 13.21 & 5 & 4 \\
\hline 21 & Ruderal grasses & 86.66 & 3 & 4 \\
\hline 22 & Park grasses & 2.01 & 3 & 5 \\
\hline 23 & Abandoned areas with ruderal vegetation & 22.41 & 2 & 3 \\
\hline 24 & Rocks, rocks reefs & 2.04 & 5 & 1 \\
\hline 25 & Grassy overgrown & 25.03 & 4 & 5 \\
\hline 26 & Forest-steppe vegetation & 6.29 & 5 & 4 \\
\hline 27 & Waterside - vegetation natural & 6.6 & 4 & 5 \\
\hline 28 & Soft alluvial forest & 52.21 & 5 & 5 \\
\hline 29 & Oak-hornbeam forest & 817.85 & 5 & 5 \\
\hline 30 & Xerothermic oak forest & 5.68 & 5 & 5 \\
\hline 31 & Pine forest & 8.5 & 5 & 5 \\
\hline 32 & Locust forest & 0.5 & 3 & 5 \\
\hline 33 & Young unspecified forest & 15.17 & 2 & 5 \\
\hline 34 & Nonforest vegetation surface, variety of species & 26.58 & 3 & 4 \\
\hline
\end{tabular}

Notes: V1 - landscape-ecological significance according to the first methodology; V2 - landscape-ecological significance according to the second methodology; 1 - very low; 2 - low; 3 - medium; 4 - high; 5 - very high.

Table 5. Comparison of the percentual representation of the landscape value based on both methodological approaches.

\begin{tabular}{|l|c|c|}
\hline Value of land supply & First methodological approach (area \%) & Second methodological approach (area \%) \\
\hline 1 & $4 \%$ & $1 \%$ \\
\hline 2 & $12 \%$ & $5 \%$ \\
\hline 3 & $9 \%$ & $6 \%$ \\
\hline 4 & $10 \%$ & $10 \%$ \\
\hline 5 & $65 \%$ & $78 \%$ \\
\hline
\end{tabular}

From the aforementioned it follows that based on the second approach, the area has the highest potential for cycling tourism, hiking, rural tourism, and cultural tourism-natural attractions. Hence, cultural-historical tourism is less important.

In our study, we offer a solution for quantifying landscape supply with demand in terms of ecosystem service usage for recreational purposes.
Since the first publication of the ecosystem services matrix, which combines land cover types with ecosystem service supply capacities (Burkhard et al., 2009), the method has been successfully used to quantify and map ecosystem services in several case studies (e.g., Kandziora et al., 2013; Kaiser et al., 2013; Müller et al., subm.). It has also inspired the development of other mapping studies of ecosystem services (e.g., Clerici et al., 2014; Baral 
Table 6. Overview of landscape area with individual types of tourism.

\begin{tabular}{|c|c|}
\hline Types of tourism & Area (ha) \\
\hline 1 & 10.6 \\
\hline 2 & 8.33 \\
\hline 3 & 0.6 \\
\hline 4 & 42.27 \\
\hline 5 & 86.66 \\
\hline 6 & 1003.35 \\
\hline 7 & 21.7 \\
\hline 8 & 2.01 \\
\hline 9 & 2.26 \\
\hline 10 & 150.18 \\
\hline$(-)$ & 64.53 \\
\hline
\end{tabular}

Notes: 1 - recreational tourism; 2 - cultural tourism aimed at cultural-historical sights; 3 - sports tourism; 4 - socially oriented tourism; 5 - cultural tourism aimed at natural attractions; 6 - relaxation-sports tourism; 7 - technical infrastructure; 8 - green infrastructure; 9 civic amenities; 10 - individual-relaxation-social; (-) - not assessed.

et al. 2013; Maes et al., 2011). An improved version was published in 2012, including ecosystem service requirements and budget estimates for ecosystem services using the same method (Burkhard et al., 2012). This method has also been used in various case studies (e.g., Kroll et al., 2012; Getzner, Jungmeier, 2009; Getzner, 2009, 2010; Nedkov, Burkhard, 2012; Burkhard et al., 2012, 2014; Mederly et al., 2020) and has been improving further.

In our study, we used an ES matrix which models a landscape's capacity to provide culture ecosystem services based on land use data or land cover data, and starts with expert estimates. The model consists of relatively simple matrices with ecosystem services in columns and elements of landscape cover, i.e., geographical units in rows.

The matrix of landscape supply evaluation in the first methodological approach assesses to a certain extent the biophysical value of land cover elements, their origin, the degree of anthropogenic pressure, and preservation. Thorough field research is important. In proposals for tourism types (social demand), they allow preservation to be sensitively taken into account, as well as sustainable use via appropriately selected tourism types.

The second methodological procedure for the evaluation of natural and cultural-historical conditions also uses the existing input database of land cover mapping, but in much less detail. It uses basic groups of landscape elements supplemented by landscape protection and cultural and historical monuments protection, where the selected indicators are used to evaluate the landscape's recreational potential. For this reason, available data from the Strategic Documents of Cities and Regions can be used for evaluation, as well as for the spatial plans of cities and municipalities. It is clearly suitable for larger territorial units at the regional level in the design of tourism types.

This procedure can also be supplemented by data on environmental infrastructure, which is a suitable indicator for ecosystem services supply (e.g., water-supply, sewerage, wastewater treatment, and waste management).

\section{Discussion}

Places for tourism in a city means the area which provides daily recreation for residents and tourists. Such essentially comprises forest, meadows, waterways, sports fields, playgrounds, etc. places outside a city, yet which have attained an essential cityrural character. Therefore, parks and forest parks, natural localities, riversides, lakesides and dams, suburban forests, etc. could be used.

We agree with the idea of Allen (2003), Masuda and Garvin (2008), Lopez-Goyburu and Garcia-Montero (2018) that spaces between urban and rural systems in a city should be evaluated as one system. This approach is also evidenced by our area, where these two systems overlap. As urbanization has become one of the key issues defining the human relationship with the ecosystem, so accordingly assessing the urban-rural system as a whole could help create cultural ecosystem services in cities (Belčáková, 2012).

Most currently available spatial ecosystem service studies focus on ecosystem service supply (see Russi et al., 2013; Sandler, 2012; Martínez-Harms, Balvanera, 2012; Mederly et al., 2020; for reviews), whereas the demand side has not been sufficiently considered. The integration of societal needs for goods and services enhances currently applied function-oriented landscape planning approaches, as well as environmental management strategies.

From the overall assessment and comparison of the two methodological approaches that propose ecological forms of tourism, we can state that both methodological approaches are based on different scales of mapping landscape elements and using different evaluation methods.

The first methodological approach takes more into consideration the degree of anthropic pressure on land cover, the origin of species, or the occurrence of protected and rare vegetation and animal species. It also offers a wider range of tourism types that respect the degree of hemeroby on ecosystems, and it suggests ways to use the specific ecological forms of tourism in a more sensitive way. As such, it can be applied for local or regional options for tourism development. In this approach, we proceed from the detailed mapping of land cover elements according to CORINE Land Cover (Bossard et al., 2000) on the third, fourth, and fifth levels. In the second methodological approach, the indicators of landscape-ecological significance are the values of natural potential, environmental structure, and tourism infrastructure. While it uses more indicators to assess ecosystem services, it also uses a relatively narrow spectrum of tourism forms and types to suggest tourism development. The assessment is based on less detailed mapping of land cover elements according to CORINE Land Cover (Bossard et al., 2000) at the first level, and as such, it is more applicable (after inserting the scope of spectrum tourism types) for regional and supra-regional conditions of an area. This study sets out to address three hypotheses:

1. Whether the selected indicators can be considered complementary, and whether the degree of subjectivity can be determined.

2. Or the selected indicators overlap and multiply the value of the elements of the terrain area, thus overestimating some segments of the landscape. From the map representations themselves, it follows that in the second methodological procedure, 
a significantly larger area of the territory belongs to the first degree of significance, such as forests, meadows, and protected areas. The design of suitable tourism types thus partially took into account the nature, originality, and rarity of elements in the localities of protected areas, which results from the character in the second methodological procedure when using the weighting of selected criteria. In the first methodological approach to mapping at the third and fourth hierarchical levels and re-evaluating LES, we obtained a much more differentiated map representation, which allows for a more sensitive and accurate design of tourism types.

3. Or the selected indicators in these methods can be considered as individual criteria.

We have come to the conclusion that the indicators used cannot be combined or considered as complementary. These are two separate methodologies, where we have mentioned the advantages and disadvantages of usage. We also found that the criteria used, especially in the second evaluation system, are marked by the authors' subjectivity.

\section{Conclusion}

In the study, we focused on researching methods for evaluating the cultural services of ecosystems in terms of developing sustainable forms of tourism. The model area was had high biodiversity. We compared two methodological approaches, which were based on different measures of mapping and interpretation of attributes of elements of the current landscape structure with regard to tourism use. We concluded that both methodological procedures are suitable for the evaluation of cultural ecosystem services with regard to the development of tourism. Yet, the first methodological procedure based on a detailed mapping of landscape cover is more suitable for smaller areas at the local level, while the second methodological procedure is more suitable at the regional or national level.

\section{Acknowledgements}

This research was supported by the project GP VEGA 02/0077/21 Integration of supply of selected ecosystem services for societal demand in terms of developing sustainable forms of tourism.

\section{References}

Allen, A. (2003). Environmental planning and management of the peri-urban interface: Perspectives on an emerging field. Environment and Ur banization, 15(1), 135-147.

Anděl, J., Balej M. \& Suchevič S. (2008). The evaluation of landscape recreational potential (in Czech). In J. Anděl, M. Balej, M. Jeřábek, T. Oršulák \& P. Raška (Eds.), Komplexní geografický výzkum kulturní krajiny (pp. 113-125). II. díl. Ústí nad Labem: Univerzita J.E. Purkyně.

Baral, H., Keenan, R.J., Fox, J.C., Stork, N.E. \& Kasel S. (2013). Spatial assessment of ecosystem goods and services in complex production landscapes: A case study from south-eastern Australia. Ecological Complexity, 13, 35-45. DOI: 10.1016/j.ecocom.2012.11.001.

Belčáková, I. (2012). Landscape planning framework in the environmenta assessment - linkages and mutual. Ekológia (Bratislava), 31(1), 1-11. DOI: 10.4149/ekol_2012_01_1.

Bossard, M., Feranec, J. \& Otahel' J. (2000). Corine land cover technical guide Addenum 2000. Copenhagen: European Environment Agency.

Burkhard, B., Kroll, F., Müller, F. \& Windhorst W. (2009). Landscapes' capacities to provide ecosystem services - A concept for land-cover based assessments. Landscape Online, 15, 1-22. DOI: 10.3097/LO.200915.
Burkhard, B., Kroll, F., Nedkov, S. \& Müller F. (2012). Mapping ecosystem service supply, demand and budgets. Ecological Indicators, 21, 17-29. DOI: 10.1016/j.ecolind.2011.06.019.

Burkhard, B., Kandziora, M., Hou, Y. \& Müller F. (2014). Ecosystem service potentials, flows and demands - concepts for spatial localisation, indication and quantification. Landscape Online, 34, 1-32. DOI: 10.3097/ LO.201434.

Clerici, N., Paracchini, M.L. \& Maes J. (2014). Landcover change dynamics and insights into ecosystem services in European stream riparian zones. Ecohydrol. Hydrobiol., 14(2), 107-120. DOI: 10.1016/j.ecohyd.2014.01.002.

DEFRA (2007). Department for environment, food and rural affairs. www. defra.gov.uk

Getzner, M. (2009). Economic and cultural values related to Protected Areas - Part A: Valuation of Ecosystem Services in Tatra (PL) and Slovensky raj (SK) national parks. Wien: Klagenfurt Universität.

Getzner, M. \& Jungmeier M. (2009). Improving protected areas. Klagenfurt: Heyn

Getzner, M (2010). Valuation of ecosystems services in Tatra (Poland) and Slovensky raj national parks. Wien: Technische Universität.

Healy, R.G. (1994). Tourist mechandise as a means of generating local benefits from ecotourism. Journal of Sustainable Tourism, 2(3), 137-142. DOI: 10.1080/09669589409510691.

Christ, C., Hillel, O., Matus, S. \& Sweeting J. (2003). Tourism and biodoversity - Mapping Tourism Global Footprint. Washington: Conservation International. http://www. uncp.org/PDF/Tourism and biodiversity report.pdf

Kaiser, G., Burkhard, B., Römer, H., Sangkaew, S., Graterol, R., Haitook, T., Sterr, H. \& Sakuna-Schwartz D. (2013). Mapping tsunami impacts on land cover and related ecosystem service supply in Phang Nga, Thailand. Natural Hazards and Earth System Sciences, 13, 3095-3111. DOI: 10.5194/nhess-13-3095-2013.

Kandziora, M., Burkhard, B. \& Müller F. (2013). Interactions of ecosystem properties, ecosystem integrity and ecosystem service indicators - A theoretical matrix exercise. Ecological Indicators, 28, 54-78. DOI: 10.1016/j. ecolind.2012.09.006

Krnáčová, Z., Štefunková, D., Dobrovodská, M., Hrnčiarová, T., Pavličková K., Pauditšová, E., Potočková, L., Košovič, P., Kubíček, F., Janotka, V. \& Gajdoš V. (2005). Integrated tourism development within the microregion Svätý Jur (in Slovak). Bratislava: ÚKE SAV.

Krnáčová, Z., Barančok, P. \& Pavličková K. (2018). Assessment of selected cultural ecosystem services: Benefits of land cover ecosystems for ecological models of tourism development (case study of Devin, the district of Bratislava IV). In Mobilities, tourism and travel behaviour contexts and boundaries (pp. 189-207). Rijeka: In Tech Open.

Krogmann, A. (2005). Current options land use Nitra region in terms tourism (in Slovak). Nitra: UKF.

Krogmann, A. (2006). Using the model of the geography of tourism on the example of border cities Komárno and Štúrovo (in Slovak). Acta Oeconomica, 19, 108-114.

Kroll, F., Müller, F., Haase, D. \& Fohrer N. (2012). Rural-urban gradient analysis of ecosystem services supply and demand dynamics. Land Use Policy, 29, 521-535. DOI: 10.1016/j.landusepol.2011.07.008.

Lopez-Goyburu, P. \& Garcia-Montero L.G. (2018). The urban-rural interface as an area with characteristics of its own in urban planning: A review. Sustainable Cities and Society, 43, 157-165. DOI: 10.1016/j. scs.2018.07.010

Maes, J., Paracchini, M.L. \& Zulian G. (2011). A European assessment of the provision of ecosystem services: Towards an Atlas of ecosystem services. Luxembourg: Publications Office of the European Union. DOI: $10.2788 / 63557$.

Maes, J., Teller, A., Erhard, M., Liquete, C., Braat, L., Berry, P., Egoh, B., Puydarrieux, P., Fiorina, C., Santos, F., Paracchini, M.L., Keune, H., Wittmer, H., Hauck, J., Fiala, I., Verburg, P.H., Condé, S., Schägner, J.P., San Miguel, J., Estreguil, C., Ostermann, O., Barredo, J.I., Pereira, H.M., Stott A., Laporte, V., Meiner, A., Olah, B., Royo Gelabert, E., Spyropoulou, R., Petersen, J.E., Maguire, C., Zal, N., Achilleos, E., Rubin A., Ledoux, L., Brown, C., Raes, C., Jacobs, S., Vandewalle, M., Connor, D. \& Bidoglio G. (2013). Mapping and assessment of ecosystems and their services. An analytical framework for ecosystem assessments under action 5 of the Biodiversity Strategy to 2020. Luxembourg: Publication office of the European Union. DOI: $10.2779 / 12398$ 
Mariot, P. (1983). Geography of the tourism (in Slovak). Bratislava: Veda vydavatelstvo $\mathrm{SAV}$.

Martínez, M.J. \& Balvanera J. (2012). Methods for mapping ecosystem service supply: A review. International Journal of Biodiversity Science, Ecosystem Services \& Management, 8(1-2), 17-25. DOI $10.1080 / 21513732.2012 .663792$

Masuda, J.R. \& Garvin T. (2008). Whose Heartland? The politics of place in a rural-urban interface. Journal of Rural Studies, 24(1), 112-123. DOI 10.1016/j.jrurstud.2007.08.003.

McCool, S.F. \& Lime D.W. (2001). Tourism carrying capacity: Tempting fantasy or useful reality? Journal of Sustainable Tourism, 9(5), 372-388. DOI: 10.1080/09669580108667409.

Mederly, P., Černecký, J., Špulerová, J., Izakovičová, Z., Duricová, V., Považan, R., Švajda, J., Močko, M., Jančovič, M., Gusejnov, S., Hreško, J., Petrovič, F., Štefunková, D., Šatalová, B., Vrbičanová, G., Kaisová, D., Turanovičová, M., Kováč, T. \& Laco I. (2020). National ecosystem services assessment in Slovakia - meeting old liabilities and introducing new methods. One Ecosystem, 5, e53677. DOI: 10.3897/oneeco.5.e53677.

Molitoris, L. \& Pavličková K. (2018). Potenciál rozvoja rekreácie - prípadová štúdia v mikroregióne Velká Javorina - Bradlo. Acta Environmentalica Universitatis Comenianae (Bratislava), 21(2), 36-47.
Müller, A., Burkhard, B., Müller, F., Grescho, V. \& Settele J. (subm.). Land cover-based ecosystem service assessment of irrigated rice cropping systems with different production intensities in Southeast Asia.

Nedkov, S. \& Burkhard B. (2012). Flood regulating ecosystem services Mapping supply and demand, in the Etropole municipality, Bulgaria. Ecological Indicators, 21, 67-79. DOI: 10.1016/j.ecolind.2011.06.022.

Otahel, J. \& Poláčik S. (1987). Landscape synthesis of Liptovská kotlina (in Slovak). Bratislava: Veda, vydavatel'stvo SAV.

Russi, D., ten Brink, P., Farmer, A., Badura, T., Coates, D., Förster, J., Kumar, R. \& Davidson N. (2013). The economics of ecosystems and biodiversity for water and wetlands. London, Brussels: IEEP.

Sandler, R. (2012). Intrinsic value. Ecology and conservation. Nature Education Knowledge, 3(10), 4.

Sláviková, D. (1975). Výskum rekreačnej hodnoty krajiny. Záverečná správa úlohy VI -3- 6/2. Zvolen: LF VŠLD.

Smejkal, J. (1999). Design of quantification of the nature of nearby woody tracks (in Czech). In I. Míchal \& V. Petríček (Eds.), Péče o chráněná území. II. Lesní společenstva (pp. 136-140). Praha: AOPaK ČR. 